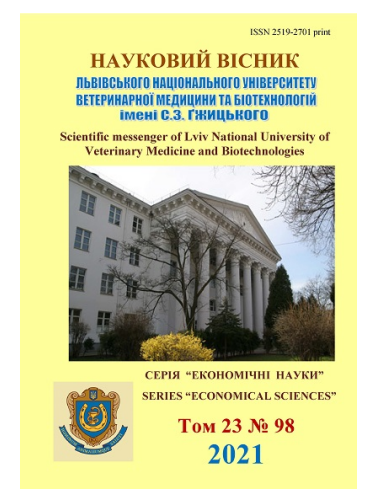

Науковий вісник Дьвівського національного університету
ветеринарної медицини та біотехнодогій імені С.З. Гжицького. Серія: Економічні науки

Scientific Messenger of Lviv National University

of Veterinary Medicine and Biotechnologies. Series: Economical Sciences

UDC 339.9

\title{
Methodological approaches to efficiency evaluation foreign economic activity agricultural enterprises
}

\author{
R. Batyuk
}

Stepan Gzhytskyi National University of Veterinary Medicine and Biotechnologies Lviv, Lviv, Ukraine

Article info

Received 11.10.2020

Received in revised form 29.11.2020

Accepted 01.12.2020

Stepan Gzhytskyi National University of Veterinary Medicine and Biotechnologies Lviv, Pekarska Str., 50, Lviv, 79010, Ukraine.

Tel.: +38-093-183-90-02

E-mail: oscar.romik@gmail.com
Batyuk, R. (2021). Methodological approaches to efficiency evaluation foreign economic activity agricultural enterprises. Scientific Messenger of Lviv National University of Veterinary Medicine and Biotechnologies. Series: Economical Sciences, 23(98), 3-11. doi: 10.32718/nvlvet-e9801

The article is devoted to topical issues of development of existing and establishment of new approaches to the methodology of assessing the effectiveness of foreign economic activity of agricultural enterprises with the subsequent formation of strategies for its development. Thanks to the successful operation of domestic agricultural enterprises in foreign markets and effective and fruitful cooperation with foreign partners, economic growth of the country as a whole is achieved. Therefore, in modern economic conditions, the increase in foreign economic activity requires a thorough methodological approach to assessing the effectiveness of foreign economic activity of agricultural enterprises. The theoretical and methodological basis of research were the works of leading domestic and foreign economists and the work of leading analysts on the problems and methodology of modeling foreign economic activity, comprehensive approaches based on a combination of economic analysis and methods of economic and mathematical modeling. The following research methods were used in solving the tasks: monographic, analysis and synthesis, expert evaluations, deduction method and abstract-logical. In order to implement the organizational and economic mechanism for determining the foreign economic activity of agricultural enterprises, we propose to use a universal method of foreign economic activity analysis and at the micro level in order to compare the obtained calculations to assess trends in the development of foreign economic activity of agricultural enterprises. If an agricultural enterprise is engaged in both exports and imports, then to assess its performance in the foreign market for a certain period can be calculated integrated indicators of foreign trade, which provide for the comparability of results achieved for the whole set of export-import operations at full cost. The initial methodological basis for assessing and analyzing the foreign economic activity of agricultural enterprises should be a systematic analysis and a comprehensive, dialectical approach, which necessitates the study of individual elements and the system as a whole in constant motion, change, in the process of constant renewal. This is important not only for understanding the essence of economic categories but also for formulating conclusions on their practical application, making management decisions at different levels of the hierarchical management system in the agricultural sector of Ukraine. The practical significance of the results of the study lies in the substantiation of the methodology, which allows to calculate and fully assess the effectiveness of foreign economic activity of any agricultural enterprise.

Key words: valuation methodology, foreign economic activity, agricultural enterprises, integrated indicator, valuation indices.

\section{Методичні підходи до оцінювання ефективності зовнішньоекономічної діяльності аграрних підприємств}

\author{
Р. Б. Батюк
}

Львівський національний університет ветеринарної медицини та біотехнологій імені С. 3. Гжсицького, м. Львів, Україна 
Стаття присвячена актуальним питанням розвитку наявних і встановлення нових підходів до методики оиінки ефективності зовнішньоекономічної діяльності аграрних підприємств із подальшим формуванням стратегій його розвитку. Завдяки успішній діяльності вітчизняних аграрних підприємств на зовнішніх ринках та ефективній й плідній співпраці з іноземними партнерами досягається економічне зростання країни у цілому. А тому в сучасних умовах господарювання підвищення ЗЕД вимагає трунтовного методичного підходу до оцінки ефективності зовнішньоекономічної діяльності аграрних підприємств. Теоретичною та методологічною основою досліджень стали прачі провідних вітчизняних та зарубіжних вчених-економістів та праці провідних аналітиків, присвячені проблемам і методології моделювання зовнішньоекономічної діяльності, комплексні підходи, ияо базуються на поєднанні економічного аналізу та методів економіко-математичного моделювання. При вирішенні поставлених завдань використовувались такі методи дослідження: монографічний, аналізу та синтезу, експертних оцінок, метод дедукиї та абстрактнологічний. 3 метою реалізації організачійно-економічного механізму визначення зовнішньоекономічної діяльності аграрних підприємств пропонуємо використовувати універсальну методику аналізу ЗЕД, яка може застосовуватись як на макро-, та і на мікрорівні з метою можливості порівняння отриманих розрахунків для оцінки тенденцій розвитку ЗЕД аграрних підприємств. Якщо аграрне підприємство одночасно займається експортом і імпортом, то для очінки його роботи на зовнішньому ринку за певний період можуть бути розраховані інтегральні показники ефективності зовнішньоторговельної діяльності, які передбачають співмірність результатів, щуо досягаються, за всією сукупністю експортно-імпортних операцій з повними витратами на них. Вихідною методичною базою для оцінки й аналізу зовнішньоекономічної діяльності аграрних підприємств має бути системний аналіз та комплексний, діалектичний підхід, щцо зумовлює необхідність вивчення окремих елементів і системи в иілому в постійному русі, змінах, в процесі постійного оновлення. Це є важливим не тільки для пізнання суті економічних категорій, але і для формулювання висновків щуодо практичного їх застосування, прийняття управлінських рішень на різних рівнях ієрархічної системи управління в аграрному секторі Украӥни. Практична значущість результатів дослідження полягає в обтрунтуванні методики, ияо дає змогу розрахувати та максимально повно оцінити ефективність зовнішньоекономічної діяльності будь-якого аграрного підприємства.

Ключові слова: методика очінювання, зовнішньоекономічна діяльність, аграрні підприємства, інтегральний показник, індекси оцінювання.

\section{Вступ}

В умовах ринкової економіки кожне підприємство самостійно визначає свою діяльність, зокрема зовнішньоекономічну. Від цього залежить розвиток підприємства, а тому здійснення зовнішньоекономічної діяльності має бути результативним та ефективним 3 формування відповідного механізму управління, який дозволить ефективно впливати на діяльність об'єкту управління 3 метою досягнення цілей підприємства при здійсненні ЗЕД.

На сучасному етапі глобалізації господарських відносин визначальним у розвитку аграрних підприємств України $\epsilon$ ефективність інтеграції аграрного сектору економіки нашої держави у систему зовнішньоекономічних зв'язків, відповідно до вимог СОТ, що вимагає суттєвого рівня його адаптованості до сучасних тенденцій зовнішнього середовища. Адже, завдяки успішній діяльності вітчизняних аграрних підприємств на зовнішніх ринках та ефективній й плідній співпраці 3 іноземними партнерами досягається економічне зростання країни у цілому. А тому в сучасних умовах господарювання підвищення ЗЕД вимагає грунтовного методичного підходу до оцінки ефективності зовнішньоекономічної діяльності аграрних підприємств.

В економічній літературі, яка представлена досить детальною системою аналізу та оцінки фінансовогосподарської діяльності підприємства у зовнішньоекономічній сферіприділено належну увагу. Проте не існує єдиного загальновизнаного підходу до оцінювання розвитку ЗЕД підприємства.

Відкритим залишається питання вибору критеріїв оцінки та аналізу ЗЕД, які дозволять окремим аграрним підприємствам залежно від виду та обсягів їхньої діяльності адекватно оцінити ефективність й визначити шляхи подальшого розвитку.

Аналіз останніх досліджень та публікаиій. Дослідження методичних аспектів оцінки ефективності зовнішньоекономічної діяльності аграрних підприємств $€$ предметом підвищеної уваги багатьох зарубіжних i вітчизняних учених, зокрема Брояка А. А. (Broiaka, 2020), Васюк Т. В. (Vasiuk, 2015), Гадзало Я. М., Лузан Ю. Я. (Hadzalo \& Luzan, 2021), Гребельник О. П. (Hrebelnyk, 2008), Каплан Р. С. (Kaplan, 2004; Kaplan \& Norton, 2006), Кернасюк Ю. В. (Kernasiuk, 2020), Кубів C. I. (Kubiv \& Fediuk, 2020), Паска I. M. (Paska, 2000), Слюсаренко А. В. (Sliusarenko, 2020), Яковлев А. I. (Yakovlev, 1998) та інші.

Однак, незважаючи на значний науковий доробок, деякі аспекти теоретичних i методологічних засад оцінювання ефективності зовнішньоекономічної діяльності аграрних ще недостатньо вивчені.

Поняття ефективності ЗЕД має комплексний і багатоаспектний характер. Воно може виражатись за допомогою різноманітних економічних показників, але найпростіший та найголовніший - це отримання прибутку від реалізацій виробленої продукції на зовнішньому ринку (Semenov, 2009).

На думку Гребельника О. П. ефективність зовнішньоекономічної діяльності - "це економічна категорія, що відображає сукупний ефект від зовнішньоекономічних зв'язків, який полягає в економії суспільної праці та зростанні її продуктивності від участі економіки країни у міжнародному поділі праці” (Hrebelnyk, 2008).

Під ефективністю зовнішньоекономічної діяльності на підприємстві слід розглядати результати виконання зовнішньоекономічних видів діяльності, які базуються на отриманні такого обсягу доходу, який забезпечує прибуток, що значно перевищує витрати на його досягнення. Окрім кількісного критерію визначення ефективності зовнішньоекономічної діяльності підприємства необхідно враховувати якісний критерій, який можемо оцінювати за рівнем виконання поставлених завдань, рівнем конкурентоспроможності продукції та послуг, що експортуються (Psiuk, 2014).

Так, I. Паска (Paska, 2000) пропонує визначати економічну ефективність зовнішньоекономічної дія- 
льності підприємства в розрізі окремих товарних груп або товарів. На його думку, ефективність зовнішньоекономічної діяльності характеризують такі показники, як валютна ефективність експорту, абсолютна ефективність, абсолютний ефект, рівень рентабельності. Рівень рентабельності автор пропонує визначати як співвідношення абсолютного ефекту від експорту і собівартості виробництва одиниці продукції з урахуванням витрат на здійснення експортної угоди. Варто зазначити, що оцінювання розвитку ЗЕД аграрних підприємств передбачає застосування набору різноманітних методів та прийомів (інструментів) та базується на певних методичних підходах.

А. Яковлєв розробив систему оцінки ефективності для різних агентів міжнародного бізнесу, дав визначення коефіцієнту кредитного впливу та виділяє такі показники оцінки ефективності зовнішньоекономічної діяльності підприємства: ефективність підприємства, яке самостійно здійснює зовнішню торгівлю, порівняно з ефективністю підприємства, яке реалізує продукцію через державні органи; ефект, який отримує бюджет держави під час реалізації продукції підприємством безпосередньо іноземному споживачу; ефект фірми-посередника, яка реалізує продукцію підприємства на зарубіжному ринку; коефіцієнт кредитного впливу на результати експортно-імпортної діяльності (Yakovlev, 1998).

Схожої думки дотримується колектив авторів Ю. Г. Козак, Н. С. Логвинова, М. А. Заєць (Kozak et al., 2012). Проте вони вважають, що доцільний поділ показників лише на дві групи: показники ефекту й показники ефективності. Оскільки експортна діяльність може супроводжуватися низкою негативних чинників, що становлять загрозу платоспроможності, ефективності діяльності підприємства, його здатності до самофінансування, то, на нашу думку, для визначення ефективності ЗЕД, окрім загальноприйнятих показників, необхідно застосовувати показники запасу економічної безпеки підприємства, які опосередковано іiі характеризують. Такі показники визначаються як різниця між фактично досягнутим обсягом виручки та іiї мінімально необхідними рівнями, що послідовно забезпечують: по-перше, достатній грошовий оборот підприємства; по-друге, покриття витрат операційної діяльності, по-трете, фінансування інвестиційної та фінансової діяльності підприємства. Зазначимо, незважаючи на відмінності в поглядах щодо класифікації системи показників, більшість авторів дотримується думки, що ефективність ЗЕД потрібно аналізувати окремо за напрямами такої діяльності, а потім визначати загальний ефект.

Мета та завдання дослідження. Зважаючи на наукову та практичну актуальність теми, метою даного дослідження $є$ розвиток наявних і встановленнянових підходів до методики оцінки ефективності зовнішньоекономічної діяльності аграрних підприємств із подальшим формуванням стратегій його розвитку.

Предметом дослідження $\epsilon$ науково-методичні та прикладні підходи до оцінювання ефективності зовнішньоекономічної діяльності аграрних підприємств.

Практична значущість результатів дослідження полягає в обгрунтуванніметодики, що дає змогу роз- рахувати та максимально повно оцінити ефективність зовнішньоекономічної діяльності будь-якого аграрного підприємства.

\section{Матеріал і методи досліджень}

Теоретичною та методологічною основою досліджень стали праці провідних вітчизняних та зарубіжних вчених-економістів, у яких розглянуто сучасні наукові погляди на економічні проблеми управління зовнішньоторговельною діяльністю, а також праці провідних аналітиків, присвячені проблемам і методології моделювання зовнішньоекономічної діяльності, комплексні підходи, що базуються на поєднанні економічного аналізу та методів економікоматематичного моделювання. При вирішенні поставлених завдань використовувались такі методи дослідження: монографічний - при висвітленні поглядів учених на досліджувані в роботі проблеми, вивченні ретроспективи розвитку оцінки ефективності зовнішньоекономічної діяльності аграрних підприємств, вітчизняного і зарубіжного досвіду); аналізу та синтезу - для оцінювання впливу окремих чинників та показників ефективності зовнішньоекономічної діяльності аграрних підприємств на їх експортний потенціал; експертних оцінок - для формування системи показників та визначення їх вагомості під час оцінювання ефективності зовнішньоекономічної діяльності аграрних підприємств; метод дедукції - при формуванні авторських рекомендацій; абстрактно-логічний - для теоретичних узагальнень та формування висновків.

\section{Результати та їх обговорення}

Класичні методичні розробки щодо визначення ефективності ЗЕД можливо використовувати як універсальні методики визначення ефективності зовнішньоекономічної діяльності підприємства. В сучасній економічній науці існує що найменше два підходи щодо визначення ефективності ЗЕД підприємства. Загально прийнятий підхід базується на розрахунку загального показника ефективності ЗЕД підприємства - прибутковості зовнішньоторговельних операцій. Він розраховується шляхом співставлення доходів і витрат, а також розрахунку стану виконання планових завдань по зовнішньоторговельних операціях (Terekhov, 2010).

Кожна економічна система, зокрема і підприємство-суб'єкт ЗЕД має в своєму розпорядженні обмежені ресурси для зовнішньоекономічної діяльності, тому, при реалізації програми виходу на зовнішній ринок, необхідно оцінити весь комплекс внутрішніх і зовнішніх можливостей підприємства (Vasiuk, 2015).

На нашу думку, оптимальна програма експорту аграрних підприємств, визначається за допомогою наступної економіко-математичної моделі (1):

$$
\begin{aligned}
& \max F=i_{I} * k_{k} * P_{i k} * X_{i k}+i_{I} * P_{l i} * X_{l i}-k_{o k o} * x * \mathrm{~J}_{\mathrm{j}} * Z_{j k} * X_{c e p j l} \\
& \text { де: } \\
& \quad i_{I}-\text { кількість видів продукції, що випускається, }
\end{aligned}
$$


$k_{k}$ - кількість зовнішніх ринків експорту продукції,

$P_{i k}$ - питомий прибуток від продажу експортної продукції і на зовнішньому ринку $\mathrm{k}$,

$J_{j}$ - кількість видів продукції, що імпортується,

$k_{\text {oko }}$ - кількість зовнішніх ринків імпорту продукції,

$X_{i k}$ - обсяг експорту продукції і на зовнішній ринок k,

$X_{l i}$ - обсяг внутрішнього виробництва продукції і,

$P_{l i}$ - питомий прибуток від реалізації продукції і на внутрішньому ринку,

$Z_{j k}$ - питомі витрати на придбання продукції імпорту

j на зовнішньому ринку $\mathrm{k}_{0}$;

$X_{c e p j k}$ - обсяг імпорту продукції ј з зовнішнього ринку $\mathrm{k}_{0}$.

Економіко-математичні методи володіють низкою переваг, що пов'язано з особливостями їх концептуальної побудови. Економіко-математичні засоби аналізують динаміку рядів числових даних із використанням об'єктивного, науково доведеного математичного інструментарію. Окрім цього, використання економіко-математичних методів дає змогу не лише оцінити перспективний напрям зміни того чи іншого індикатора, на їх основі можливо визначити кількісні прогнозні значення показників, що аналізуються (Kubiv \& Fediuk, 2020).

Методика, на наш погляд, має практичну значимість, оскільки ефективність зовнішньоекономічної діяльності аграрних підприємств формується під впливом зовнішніх і внутрішніх чинників. Кількісна оцінка цього впливу є важливою при визначенні ефективності зовнішньоекономічної діяльності підприємства. Проте, при оцінці валютної ефективності зовнішньоекономічної діяльності, необхідно враховувати фактор перерахунку іноземної валюти в національну валюту і назад за офіційним курсом НБУ, який не відображають реального співвідношення купівельної спроможності іноземних валют і національної валюти, що впливає на достовірність і об'єктивність результатів дослідження.

3 метою реалізації організаційно-економічного механізму визначення зовнішньоекономічної діяльності аграрних підприємств пропонуємо використовувати універсальну методику аналізу ЗЕД, яка може застосовуватись як на макро-, та і на мікрорівні з метою можливості порівняння отриманих розрахунків для оцінки тенденцій розвитку ЗЕД аграрних підприємств. 3 цією метою пропонується застосувати методи динамічного програмування, а саме розв'язати рівняння Р. Беллмана (Bellman, 1969): (2)

$$
F_{n(x)}=\max ^{*}\left\{g(y)+h(x-y)+F_{n}-1 *[a y+b(x-y)]\right\}
$$

де:

$F_{n(x)}$ - максимальний дохід від n-крокового процесу,

$n$ - кількість етапів (кроків) розвитку процесу,

$(x)$ - певна кількість ресурсів,

$g(y)$ - дохід, який приносить (у),

$(y)$ - один об'єкт, до якого вкладається певна кількість ресурсів (х), $h(x-y)$ - максимальний дохід, який приносить (x-y),

$(x-y)$ - другий об'єкт, до якого вкладається інша кількість ресурсів (х),

$(a y)$ - величина, до якої зменшується кількість (у) до початку наступного періоду,

$b(x-y)$ - величина, до якої зменшується кількість (ху) до початку наступного періоду.

Потреба в оцінюванні зовнішньоекономічної діяльності підприємств аграрного сектору виникає тоді, коли підприємство намагається знайти способи щодо поліпшення своїх поточних ринкових позицій чи виходу на нові ринки. За необхідності реалізації таких цілей виникає необхідність оцінювання потенціалу нового ринку, розрахунку необхідних інвестицій та дослідження можливостей щодо вдосконалення товарного ринкового асортименту підприємства. Вирішення цих завдань потребує детального аналізу, який і відбувається шляхом реалізації наступних етапів оцінювання зовнішньоекономічної діяльності підприємств аграрного сектору (Kubiv \& Fediuk, 2020).

Економічне обгрунтування діяльності підприємства, у тому числі і тих напрямків, які пов'язані із зовнішньоекономічною сферою господарювання, здійснюється на підставі аналізу показників ефективності, які поділяють на показники ефекту та показники ефективності (Voronkova, 2009).

Для економічного обгрунтування прийнятих piшень та управління зовнішньоекономічною діяльністю аграрних підприємств можуть використовуватися різні методики ії оцінки. Розглянемо деякі з них.

На практиці поширеним способом оцінки ефективності ЗЕД підприємства $є$ розрахунок різних показників на основі порівняння досягнутих економічних результатів 3 витратами ресурсів на їх досягнення. В якості основних кількісних показників оцінки результативності експорту аграрних підприємств, на наш погляд, потрібно використовувати наступні:

Коефіцієнт ефективності експорту:

$$
K_{\text {л }}=\frac{Д_{e}}{\left(C m_{a}+T_{ю}+\Pi_{p}\right)}=\frac{Д_{e}}{3_{e}},
$$

де, $C m_{a}$ - собівартість експортованого товару;

$T_{ю}$ - транспортно-експедиторські витрати;

$\Pi_{p}-$ інші витрати (укладення угоди, страхування товару, платіжно-розрахункові операції, мито і збори під час перевезення товару через митний кордон та ін).

Якщо Кл> 1, то експорт ефективний (чим вище зазначений коефіцієнт, тим вища ефективність експорту);

Коефіцієнт ефекту експорту:

$$
K_{ю}=O_{n \phi}+B_{p}-3_{e},
$$

де, $O_{n \phi}$ - грошовий еквівалент відрахувань до валютного фонду підприємства, визначається перерахунком валютної виручки (підлягає обов'язковому продажу державі) в гривні за курсом на дату надходження валюти; 
$B_{p}-$ грошова виручка від обов'язкового продажу частини валюти державі.

Так, як при оцінці коефіцієнта ефективності і коефіцієнта ефекту експорту аграрних підприємств враховується низка чинників (кількість експортованого товару, контрактні ціни, динаміка валютного курсу, рівень накладних витрат в інвалюті і в гривнях, виробнича собівартість товару тощо), їх розрахунок дає змогу визначити вплив цих чинників на результат за допомогою методів детермінованого факторного аналізу.

Факторний аналіз зміни коефіцієнта ефективності експорту товару аграрних підприємствза кожною групою товарів розраховується за наступною формулою:

Коефіцієнт ефективності експорту товару за кожною групою товарів:

$$
K_{e}=\frac{\left(K * Ц *_{3}\right)}{(K * c)+H_{2 p н}}
$$

де, $K$ - кількість експортованого товару;

$Ц$ - контрактні ціни;

$P$ - динаміка валютного курсу;

$H_{\mathrm{i}}$ - рівень накладних витрат в іноземній валюті;

$H_{\text {грн }}$ - рівень накладних витрат в гривнях;

3 - виробнича собівартість товару.

При аналізі та оцінці ефективності експортних операційаграрних підприємств, в першу чергу, визначають зміни в товарній структурі експорту підприємств та зміни в географічному напрямку експорту. Також аналізується виконання умов контрактів за термінами поставок і розраховується узагальнюючий коефіцієнт прострочених зобов'язань за наступною формулою:

Узагальнюючий коефіцієнт прострочених зобов'язань:

$$
\mathrm{KK}=\frac{\Sigma \mathrm{BK}_{\mathrm{K}}}{\Sigma \mathrm{EKE}} \mathrm{X} 100
$$

де, $B_{\kappa}-$ вартість товару по всіх контрактах, які прострочені за рік;

$\mathrm{B}_{\text {кв }}$ - вартість товару по всіх контрактах, які підлягають виконанню за рік.

Розрахунок економічного ефекту експорту товару аграрних підприємств провадять за формулою:

Економічний ефект експорту товару:

$$
E_{e}=B_{e \kappa m}-C_{e c},
$$

де, $\mathrm{B}_{\text {ект }}$ - виручка від експорту товару в грошових одиницях і за офіційним курсом країни-експортера;

$\mathrm{C}_{\text {ек }}$ - всі витрати підприємства на цей товар в грошовій оцінці країни-експортера.

Економічний ефект розраховується в грошових одиницях, тому будь-яка його позитивна величина $є$ підставою для пошуку можливостей збільшення експорту з урахуванням досягнутого рівня виробництва. Цезумовлює перспективу розширення сегменту зовнішньоекономічних відносин, що за будь-яких обставин $є$ позитивним для аграрних підприємств.
Розрахунок економічної ефективності експорту товару (\%)аграрних підприємств здійснюється за формулою:

Економічна ефективність експорту товару (\%):

$$
\mathrm{E}_{\mathrm{s}}=\frac{\mathrm{B}_{\mathrm{gKr}}}{\mathrm{C}_{\mathrm{ex}}} \times 100
$$

Показник ефективності експорту є відносною величиною і набуває більшої ваги при економічному аналізі ЗЕД аграрних підприємств, ніж абсолютний показник економічного ефекту.

Аналіз імпортних операцій аналогічний аналізу експортних, за допомогою якого звітні обсяги порівнюються з плановими і минулого року, визначаються зміни у товарній структурі, а також зміни у географічному напрямку експорту (Voronkova, 2009).

В практичних розрахунках використовується низка коефіцієнтів, за допомогою яких оцінюється ефективність імпортних операційаграрних підприємств: коефіцієнт ефективності імпорту товарів для перепродажу; коефіцієнт ефективності імпорту товарів для власного виробництва; економічний ефект імпорту товарів для власного виробництва (Radchenko, 2007).

Коефіиієнт ефективності імпорту товарів для перепродажу:

$$
\mathrm{I}_{\mathrm{sd}}=\frac{\mathrm{I}_{\mathrm{i}}}{\mathrm{C}_{\mathrm{n} 1}+\mathrm{T}_{\mathrm{j}}+\mathrm{I}_{1}}=\frac{\mathrm{I}_{1}}{3_{\mathrm{BI}}}
$$

Коефіиієнт ефективності імпорту товарів для власного виробництва:

$$
\mathbf{K}_{\mathrm{sd}}=\frac{\mathbf{B}_{18}}{\mathrm{C}_{\mathrm{s} 1}+\mathrm{T}_{1}+\Pi_{1}+3_{\mathrm{gn}}}
$$

де, $\mathrm{C}_{\mathrm{тi}}-$ вартість товару;

$\mathrm{T}_{\mathrm{i}}$ - транспортно-експедиторські витрати;

$\Pi_{i}-$ інші витрати;

Дi - імпортний дохід;

$3_{\text {вп }}-$ витрати на імпорт.

Економічний ефект імпорту товарів для власного виробництва:

$$
E_{e b}=O_{i} 3-Ц_{i},
$$

де, 3 - повні витрати на придбання (виготовлення) та використання

вітчизняної продукції, альтернативної імпортної продукції, (грн.);

$Ц_{\mathrm{i}}$ - ціна споживання імпортного товару (продукціï), тобто всі витрати за весь період служби імпортного товару, продукції, (грн.).

Якщо аграрне підприємство одночасно займається експортом і імпортом, то для оцінки його роботи на зовнішньому ринку за певний період можуть бути розраховані інтегральні показники ефективності зовнішньоторговельної діяльності, які передбачають співмірність результатів, що досягаються, за всією сукупністю експортно-імпортних операцій з повними витратами на них.

Для розрахунків і визначення економічної ефективності імпортної діяльності аграрних підприємств застосовують дві групи показників:

- показники ефективності імпорту товарів виробничого призначання для виробничої діяльності; 
- показники ефективності імпорту товарів кінцевого споживання для реалізації на внутрішньому ринку.

При розрахунку показників економічного ефекту імпорту товарів і ресурсів виробничого призначення визначають повну їх вартість за формулами 12 i 13.

Показники економічного ефекту імпорту товарів $i$ ресурсів виробничого призначення:

$$
\begin{gathered}
B=Ц+E_{6}, \\
E_{6}=(M+e+p+3) N,
\end{gathered}
$$

де, В - повна вартість покупки в умовах ії використання, (грн.);

Ц - купівельна ціна імпортованих виробничих ресурсів, (грн.);

$\mathrm{E}_{\mathrm{B}}$ - експлуатаційні витрати при використанні цих виробничих ресурсів, (грн.);

м - вартість матеріалів на одиницю продукції, яка випускається за участю цих ресурсів;

е - вартість палива та енергії на одиницю продукції;

p - питома вартість ремонтів на одиницю продукції;

3 - заробітна плата основних робітників на одиницю продукції;

$\mathrm{N}$ - програма випуску продукції, на яку розраховує виробник.

Здійснюючи такий аналіз, необхідно звернути увагу на вплив чинника підвищення якості продукції, заради чого найчастіше імпортуються виробничі ресурси ізтехнологічно розвинених країн.

Показник економічної ефективності імпорту ресурсів виробничого призначенняаграрних підприємств розраховується за формулою (Ekonomichnyi analiz..., 2004):

Показник економічної ефективності імпорту ресурсів виробничого призначення:

$$
I K_{M}=\frac{Q_{\min }}{B_{4 m}}
$$

де, $\mathrm{Q}_{\text {im }}$ - обсяг товарної продукції, що випускається за участю імпортованих ресурсів у середньорічних цінах.

Якщо аграрне підприємство імпортує товар для його подальшої реалізації на внутрішньому ринку, економічний ефект імпорту обчислюється за формулою:

Показник економічного ефекту імпорту товарів для реалізації на внутрішньому ринку:

$$
\mathrm{E}_{\mathrm{IM}}=\frac{\mathrm{I}_{\mathrm{B}}}{\mathrm{I}_{\mathrm{IMN}}} \mathrm{X} 100
$$

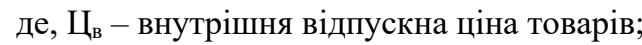

$Ц_{\text {iм }}$ - імпортна фактурна вартість товару.

Для аграрних підприємств, що займається експортом та імпортом одночасно оцінки їх роботи на зовнішньому ринку за певний період може бути розрахо- вана за допомогою інтегральних показників ефективності зовнішньоторговельної діяльності.

Показник інтегрального економічного ефектуаграрних підприємств від експортно-імпортної діяльності може бути розрахований за формулою:

Показник інтегрального економічного ефекту від експортно-імпортної діяльності:

$$
E E_{\text {екс-іми }}=E E_{\text {екс }}+E E_{\text {імn }}
$$

де, $\mathrm{EE}_{\text {екс }}$ - сумарний економічний ефект від експорту, наведений до проміжку часу, за який визначається ефект (вартісний показник). Може бути визначений як сума ефектів за всіма експортними операціями.

$\mathrm{EE}_{\text {iмп }}$ - сумарний економічний ефект від імпорту, наведений до проміжку часу, за який визначається ефект (вартісний показник). Може бути визначений як сума ефектів за всіма імпортними угодами.

Для розрахунку інтегрального показника ефективності експортно-імпортної діяльності аграрних підприємств за відповідний період часу можна використати наступну формулу (Ekonomichnyi analiz..., 2004):

Інтегральний показник ефективності експортноімпортної діяльності підприємства:

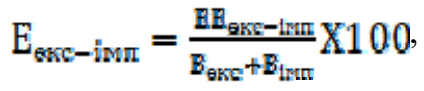

де, Ее $_{\text {кс-імп }}-$ інтегральний показник ефективності експортно-імпортної діяльності, \%;

$\mathrm{B}_{\text {екс }}$ - повні витрати на експорт, наведені до проміжку часу, за який визначається економічна ефективність, (грн.);

$\mathrm{B}_{\text {імп }}$ - повні витрати на імпорт, наведені до проміжку часу, за який визначається економічна ефективність, грн.

При обгрунтованому підборі індексів оцінювання зовнішньоекономічної діяльності аграрних підприємств доцільно керуватись певними вимогами, а саме: кожен індекс повинен характеризуватись економічним змістом, тобто повинно бути чітко виражене його функціональне призначення; для об'єктивності результатів розрахунок індексів повинен грунтуватись на доступній інформаційній базі; під час розрахунку індексівпотрібно враховувати взаємозв'язки між ними. 3 урахуванням вищенаведених вимог до системи індикаторів оцінювання експортної діяльності доцільно зараховувати такі:

Оцінювання ефективності зовнішньоекономічної діяльності аграрних підприємствповинна проводитись за 6 параметрами, кожен з яких оцінює результативність поставленої мети (табл. 1).

Складність та багатогранність зовнішньоекономічної діяльності не дозволяють вибрати один показник результативності з кількості узагальнюючих результативних показників. 
Таблиця 1

Індекси оцінки ефективності ЗЕД аграрних підприємств

\begin{tabular}{|c|c|c|}
\hline Назва & Формула & Економічний зміст \\
\hline $\begin{array}{l}\text { Індекс } \\
\text { вартості }\end{array}$ & $I_{\mathrm{sspr}}=\frac{\sum_{1=1}^{M} Q_{11} P_{11}}{\sum_{=1}^{n} Q_{10} P_{10}}$ & $\begin{array}{l}\text { відображає зміни обсягу виробництва продукції у звітному періоді по } \\
\text { відношенню до базового }\end{array}$ \\
\hline Індекс ціни & $I_{\text {ulm }}=\frac{\sum_{1=1}^{m} Q_{11} P_{11}}{\sum_{11}^{n} Q_{11} P_{10}}$ & характеризує зміну в середньому ціни на товари \\
\hline $\begin{array}{l}\text { Індекс фізично- } \\
\text { го обсягу }\end{array}$ & $I_{\text {dis.a }}=\frac{\sum_{i=1}^{n} Q_{1} P_{1 w}}{\sum_{i=1}^{n} Q_{10} P_{1 \Omega}}$ & характеризує зміни вартості обсягу товарів при незмінних цінах \\
\hline $\begin{array}{l}\text { Індекс } \\
\text { кількості }\end{array}$ & $I_{\mathrm{kL} / \mathrm{K}}=\frac{\sum_{\mathrm{l}=1}^{n} Q_{11}}{\sum_{\mathrm{l}=1} Q_{10}}$ & $\begin{array}{l}\text { відображає кількісну зміну обсягу виробництва періоду, що аналізу- } \\
\text { ється по відношенню до базового }\end{array}$ \\
\hline $\begin{array}{c}\text { Індекс } \\
\text { кількісної } \\
\text { структури }\end{array}$ & $I_{\mathrm{erpms}}=\frac{\sum_{1=1}^{n} Q_{11} P_{10}}{\sum_{\mathrm{I}=1} Q_{11} P_{10}}$ & $\begin{array}{l}\text { визначає підвищення частки дорожчих товарів в межах товарної групи } \\
\text { за рахунок зниження частки дешевих товарів }\end{array}$ \\
\hline $\begin{array}{l}\text { Середня ціна } \\
\text { товару }\end{array}$ & $\mathrm{P}_{10}=\frac{\sum_{1=1}^{n} Q_{10} P_{10}}{\sum_{1=1}^{n} Q_{10}}$ & $\begin{array}{l}\text { відображає середнє значення ціни експорту (імпорту) за аналізований } \\
\text { період часу (рік, квартал, місяць) }\end{array}$ \\
\hline
\end{tabular}

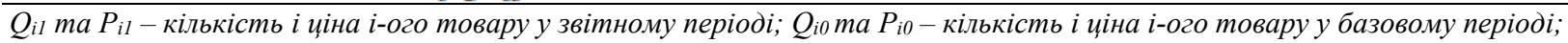
$n$-кількість видів товарів.

Джерело: побудовано за даними (Kaplan, 2004; Kaplan \& Norton, 2006)

Вибір критерію для оцінки ефективності зовнішньоекономічної діяльності залежить від цілей підприємства, особливостей ситуації на ринку, наявності інформації про внутрішнє та зовнішнє середовища. Тому виникає потреба у виборі оптимального способу виходу на зовнішній ринок на основі комплексної оцінці зовнішньоекономічної діяльності господарюючого суб'єкта.

Для того щоб спланувати зовнішньоекономічну діяльність будь-якого аграрного підприємства на перспективу, необхідно оцінити ЗЕД на даний період часу. На основі такої інформації можлива розробка нової стратегії, спрямованої на удосконалення експортноімпортних операцій підприємств.

Для оцінки власних потенційних можливостей на зовнішньому ринку та розробки заходів підвищення конкурентоспроможності й забезпечення максимального прибутку аграрним підприємствамнеобхідно проводити комплексний економічний аналіз виробничо-господарської діяльності в цілому і зовнішньоеко- номічної діяльності зокрема. Оцінка показників ефективності зовнішньоекономічної діяльності зумовлює ступінь зацікавленості аграрного підприємства у виході на світовий ринок, дає змогу обгрунтувати окремі позиції щодо закупівлі та продажу певних товарів. Одержані дані використовують при розробленні планів експортно-імпортних операцій підприємства та при оцінюванні й аналізі структури ті напрямків зовнішньоторговельного обороту (табл. 2).

Вихідною методичною базою для оцінки й аналізу зовнішньоекономічної діяльності аграрних підприємств має бути системний аналіз та комплексний, діалектичний підхід, що зумовлює необхідність вивчення окремих елементів і системи в цілому в постійному русі, змінах, в процесі постійного оновлення. Це $\epsilon$ важливим не тільки для пізнання суті економічних категорій, але i для формулювання висновків щодо практичного їх застосування, прийняття управлінських рішень на різних рівнях ієрархічної системи управління в аграрному секторі України.

\section{Таблиця 2}

Показники оцінки ефективності ЗЕД аграрних підприємств

\begin{tabular}{|c|c|c|}
\hline Назва & Формула & Необхідні дані \\
\hline $\begin{array}{l}\text { Ефективність виробни- } \\
\text { цтва продукції на екс- } \\
\text { порт }\end{array}$ & $\mathrm{K}_{\mathrm{eWF}}^{\mathrm{BWp}}=\frac{\mathrm{IT}_{\mathrm{axE}}}{\mathrm{C}_{\mathrm{genI}}}$ & $\begin{array}{l}\text { Цекс - вартість реалізованих товарів в експортних цінах, (грн.); } \\
\text { Среал - собівартість виробництва і реалізації експортної проду- }_{\text {кції, (грн.) }}\end{array}$ \\
\hline $\begin{array}{l}\text { Ефективність викорис- } \\
\text { тання імпортного това- } \\
\text { ру }\end{array}$ & $\mathrm{K}_{\mathrm{imm}}^{\mathrm{Bwp}}=\frac{\mathrm{C}_{\mathrm{imm}}^{\mathrm{BH}}}{\mathrm{L}_{\mathrm{lmm}}}$ & 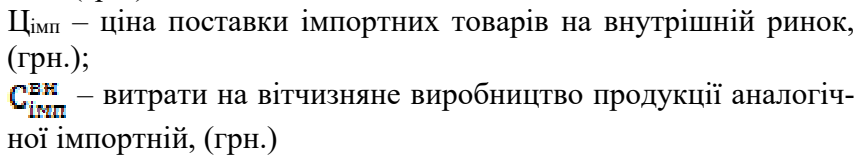 \\
\hline Ефект експорту & 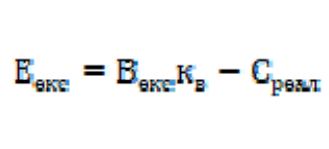 & $\begin{array}{l}\text { Векс - виручка від експорту продукції, (вал.од.); } \\
\text { Среал - витрати на виробництво та реалізацію експортованої }_{\text {продукції, (грн.); }} \\
\text { kв - валютний курс }\end{array}$ \\
\hline Ефект імпорту & $E_{\text {limm }}=\amalg_{1 \mathrm{~mm}}$ & $\begin{array}{l}\text { Цімп }_{\text {м ціна імпорту, (вал.од.); }} \\
\text { Вімп }_{\text {витрати на імпорт, (грн) }} \\
\mathrm{k}_{\text {в }} \text { - валютний курс }\end{array}$ \\
\hline
\end{tabular}




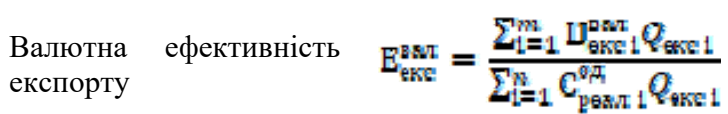

\begin{tabular}{|c|c|}
\hline $\begin{array}{l}\text { Валютна ефективність } \\
\text { iмпорту }\end{array}$ & 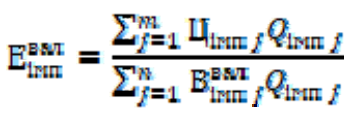 \\
\hline $\begin{array}{l}\text { Економічна (абсолютна) } \\
\text { ефективність імпорту } \\
\text { товарів }\end{array}$ & $\mathrm{E}_{\text {ekg }}^{\operatorname{lngm}}=\frac{\mathrm{L}_{\operatorname{lmm}}^{\mathrm{Bn}}}{\mathrm{B}_{\mathrm{lmm}}}$ \\
\hline $\begin{array}{l}\text { Ефективність реалізації } \\
\text { експортних товарів на } \\
\text { внутрішньому ринку }\end{array}$ & 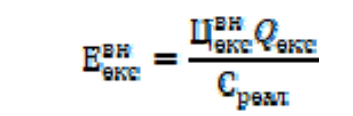 \\
\hline
\end{tabular}

цеке Qекс - обсяг експорту i-ого товару, (натур.од.);

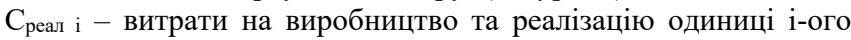
товару, (грн/од.);

$\mathrm{m}$ - кількість назв товарів чи послуг

Цімпј - ціна ј-ого товару чи послуги на внутрішньому ринку, (грн/од.);

Qімп - обсяг імпорту ј-ого товару, (натур.од.);

$\mathrm{B}_{\lim f}^{\mathrm{gs}}-$ валютна ціна (ціна придбання).

ц (грн);

$\mathrm{B}_{\text {імп }}$ витрати на придбання імпортованої продукції, (грн).

Qекс - обсяг експорту, (натур. од.);

цеке - ціни на продукцію, аналогічну експортованій на внутрішньому ринку, (грн); $\mathrm{C}_{\text {реал }}$ - витрати на виробництво та реалізацію в Україні усієї партії експортної продукції, (грн).

Джерело: побудовано за даними (Kaplan, 2004; Kaplan \& Norton, 2006)

\section{Висновки}

Отже, сукупне і вибіркове використання усіх викладених методичних підходів на основі використання уже сформованої послідовності етапів оцінювання зовнішньоекономічної діяльності аграрних суб'єктів господарювання з врахуванням рівня їх спеціалізації та гнучкості має суттєве значення для аналізу конкурентоспроможності у системі ринкових відносин, забезпечує достатню достовірність одержаних оцінок і прогнозних даних, дозволяє правильно оцінити конкретні моменти розвитку зовнішньоекономічної діяльності та мінливості кон'юнктури світового ринку сільськогосподарської продукції і на цій основі визначити перспективні й раціональні шляхи підвищення ефективності зовнішньоекономічної діяльності вітчизняних аграрних підприємств.

Комплексний економічний аналіз ефективності зовнішньоекономічної діяльності аграрних підприємства дозволяє раціонально обгрунтувати найоптимальніші обсяги пропозицій щодо реалізації товару, уникнути можливості збитків через недостатнє аргументування економічної ефективності зовнішньоекономічних операцій, обсягу реалізації продукції, іiї асортименту чи ціни через зміну валютних курсів.

Перспективи подальших досліджень. У подальшому планується дослідити показники ефективності зовнішньоекономічної діяльності аграрних підприємств, які дозволяють виявляти економічну привабливість зовнішньоекономічних операцій та розробляти заходи щодо їх вдосконалення задля збільшення прибутку агроформувань.

\section{References}

Bellman, R. (1969). Dinamicheskoe programmirovanie i sovremennaya teori upravleniya. Per. s angl. M.: Delo (in Russian).

Bilianskyi, Yu. O. (2020). Rezultatyvnist instytutsiinoho zabezpechennia intehratsiinykh protsesiv u zovnishnoekonomichnoi diialnosti ahrarnykh pidpryiemstv Ukrainy. Innovatsiina ekonomika, 1-2(82), 105-116. doi: 10.37332/2309-1533.2020.1-2.16 (in Ukrainian).
Broiaka, A. A. (2020) Perspektyvy rozvytku zovnishnoekonomichnoi diialnosti pidpryiemstv APK. Ekonomika, finansy, menedzhment: aktualni pytannia nauky i praktyky, 1, 146-159 doi: 10.37128/24114413-2020-1-10 (in Ukrainian).

Buniak, N. M., \& Danylko, I. M. (2019). Mekhanizm zovnishno-ekonomichnoi diialnosti na rynku nasinnia zernovykh kolosovykh kultur. Ekonomika APK, 2, 4247. doi: 10.32317/2221-1055.201902042 (in Ukrainian).

Dukhnytskyi, B. V. (2021). Perspektyvy zovnishnoi torhivli ahroprodovolchoiu produktsiieiu mizh Ukrainoiu ta krainamy Azii. Ekonomika APK, 4, 68-75. doi: 10.32317/2221-1055.202104068 (in Ukrainian).

Ekonomichnyi analiz finansovo-hospodarskoi diialnosti. (2004). Pidruchnyk dlia SR prof. M.: Ekonomist (in Ukrainian).

Hadzalo, Ya. M., \& Luzan, Yu. Ia. (2021). Zovnishnoekonomichna diialnist ta rezultatyvnist funktsionuvannia ahrarnoho sektoru ekonomiky Ukrainy. Ekonomika APK, 4, 6-17. doi: 10.32317/2221-1055.202104006 (in Ukrainian).

Hrebelnyk, O. P. (2008). Osnovy zovnishnoekonomichnoi diialnosti: pidruchnyk. 3-tie vyd., pererob. ta dop. K.: Tsentr navchalnoi literatury. URL: http://xn-elajqk.kiev.ua/wp-content/uploads/2019/12/grebelnik-oposnovi-zovnshnoekonomchnoyi-dyalnost_9abbed0.pdf (in Ukrainian).

Kaplan, R. S. (2004). Organizaciya, orientirovannaya na strategiyu. Kak v novoj biznes-srede preuspevayut organizacii, primenyayushchie sbalansirovannuyu sistemu pokazatelej. per. s angl. M.: Al'pinaBiznes Buks (in Russian).

Kaplan, R. S., \& Norton, D. P. (2006). Sbalansirovannaya sistema pokazatelej. Ot strategii k dejstviyu. 2-e izd., ispr. i dop. per. s angl. M.: ZAO "Olimp-Biznes" (in Russian).

Kernasiuk, Yu. V. (2020). Zastosuvannia metodu DEA dlia otsinky rozvytku ahrarnoho sektoru ekonomiky. Ekonomika APK, 10, 14-21 doi: 10.32317/22211055.202010014 (in Ukrainian).

Kozak Iu. H., Lohvinova N. S., Kovalevskyi V. V. ta in. (2012). Zovnishnoekonomichna diialnist pidpryiemstv: navch. posib. Odes. nats. politekhn. un-t 4-te vyd., pererob. ta dop. Kyiv: Osvita Ukrainy. URL: 
http://dspace.opu.ua/jspui/handle/123456789/9474 (in Ukrainian).

Kubiv, S. I., \& Fediuk, V. V. (2020). Analizuvannia ta oriien-tuvannia faktoriv, yaki vplyvaiut na rozvytok zovnish-noekonomichnoi diialnosti pidpryiemstv ahrarnoho sektoru. Visnyk KhDU. Seriia "Ekonomichni nauky", 40, 25-29. doi: 10.32999/ksu2307-8030/202040-4 (in Ukrainian).

Kubiv, S. I., \& Fediuk, V. V. (2020). Etapy otsiniuvannia rozvytku zovnishnoekonomichnoi diialnosti pidpryiemstv ahrarnoho sektoru ta yikh interpretatsiia. Ekonomichnyi prostir. Zbirnyk naukovykh prats, 160, 78-81. doi: 10.32782/2224-6282/160-14 (in Ukrainian).

Paska, I. M. (2000). Orhanizatsiia ta ekonomichna efektyvnist zovnishnoekonomichnoi diialnosti pidpryiemstv APK: avtoref. dys. ... k.e.n. Mykolaiv (in Ukrainian).

Pitel, N. Ya., \& Diachenko, M. I. (2021). Vplyv investytsiinoho klimatu na zovnishnoekonomichnu diialnist v ahrarnomu sektori. Efektyvna ekonomika, 3. doi: 10.32702/2307-2105-2021.3.89 (in Ukrainian).

Psiuk, R. M. (2014). Determinanty efektyvnosti zovnishnoekonomichnoi diialnosti promyslovykh pidpryyemstv. Tezy dopovidei V Mizhnarodnoi naukovopraktychnoi konferentsii "Upravlinnia innovatsiinym protsesom v Ukraini: nalahodzhennia vzaiemodii mizh uchasnykamy". Lviv: Vydavnytstvo Lvivskoi politekhniky, 98-99. URL: http://ena.lp.edu.ua:8080/ bitstream/ntb/28617/1/53-98-99.pdf (in Ukrainian).

Puhachov, M. I. (2019). Rozvytok zovnishnoi torhivli ahroprodovolchymy tovaramy. Ekonomika APK, 3, 613. doi: 10.32317/2221-1055.201903006 (in Ukrainian).

Radchenko, Yu. V. (2007). Analiz finansovoi zvitnosti: Navchalnyi posibnyk dlia vuziv. 2-he vyd., Dop. Rostov n / D: Feniks (in Ukrainian).

Seheda, S. A. (2019). Ahrarno-prodovolcha produktsiia v tovarnii strukturi zovnishnoi torhivli Ukrainy.
Ekonomika APK, 2, 73-83. doi: 10.32317/22211055.201902073 (in Ukrainian).

Semenov, H. A. (2009). Ekonomichna efektyvnist zovnishnoekonomichnoi diialnosti aktsionernoho tovarystva. Ekonomichnyi visnyk Donbasu, 4(18), 5459 (in Ukrainian).

Shebanin, V. S., \& Kormyshkin, Yu. A. (2019). Formy innovatsiinoi aktyvizatsii ahrarnoho pidpryiemnytstva v umovakh tsyfrovoi transformatsii ekonomiky. Ekonomika APK, 10, 18-25. doi: 10.32317/22211055.201910018 (in Ukrainian).

Sliusarenko, A. V. (2020). Kilkisni ta yakisni kharakterystyky zovnishnoekonomichnoi diialnosti ahrarnoho sektoru Ukrainy. Skhidna Yevropa: ekonomika, biznes ta upravlinnia, 4(27), 68-75. doi: 10.32782/easterneurope.27-12 (in Ukrainian).

Terekhov, Ye. M. (2010). Ekonomichni aspekty zovnishnoi polityky Ukrainy v suchasnykh umovakh hlobalnoho svitu. Mekhanizm rehuliuvannia ekonomiky, 2(3), 79-83 (in Ukrainian).

Vasiuk, T. V. (2015). Metody doslidzhennia ta vyznachennia ekonomichnoi efektyvnosti zovnishnoekonomichnoi diialnosti subiektiv hospodariuvannia. Aktualni problemy ekonomiky, 3, 131-136. URL: http://nbuv.gov.ua/UJRN/ ape_2015_3_17 (in Ukrainian).

Vodianka, L. D., \& Yurii, T. P. (2020). Tsyfrovizatsiia ta tsyfrova platforma $\mathrm{V}$ ekonomichnomu rozvytku ahrarnoho sektoru. Ekonomika APK, 12, 67-73. doi: 10.32317/2221-1055.202012067 (in Ukrainian).

Voronkova, A. E. (2009). Otsinka dii mekhanizmu upravlinnia zovnishnoekonomichnoiu diialnistiu pidpryiemstva. Prometei: rehionalnyi zbirnyk naukovykh prats z ekonomiky. Donetsk: DEHI, 1(28), 199-202 (in Ukrainian).

Yakovlev, A. Y. (1998). Usovershenstvovanie metodov opredeleniya effektivnosti vneshneekonomicheskoj deyatel'nosti. Finansy Ukrainy, 9, 28-34 (in Russian). 